\title{
Aerobic Gram Negative Bacillus
}

National Cancer Institute

\section{Source}

National Cancer Institute. Aerobic Gram Negative Bacillus. NCI Thesaurus. Code C86116.

Any rod shaped bacteria with an oxygen based metabolism and has a cell wall that

contains low levels of peptidoglycan and stains pink with the Gram staining technique. 